\title{
Comparative in vitro study and biomechanical testing of two different magnesium alloys
}

Journal of Biomaterials Applications 2014, Vol. 28(8) 1264-1273 (C) The Author(s) 2013 Reprints and permissions: sagepub.co.uk/journalsPermissions.nav DOI: 10.1 I 77//08853282। 3506758 jba.sagepub.com

(3)SAGE

\author{
Andreas Weizbauer ${ }^{1,2}$, Christian Modrejewski', Sabine Behrens ${ }^{3}$, \\ Helmut Klein ${ }^{4}$, Patrick Helmecke ${ }^{5}$, Jan-Marten Seitz ${ }^{3}$, Henning Windhagen', \\ Kai Möhwald ${ }^{3}$, Janin Reifenrath ${ }^{6}$ and Hazibullah Waizy
}

\begin{abstract}
In this in vitro study, magnesium plates of ZEKIO0 and $\mathrm{MgCa0.8}$ alloy similar to common titanium alloy osteosynthesis plates were investigated as degradable biomedical materials with a focus on primary stability. Immersion tests were performed in Hank's Balanced Salt Solution at $37^{\circ} \mathrm{C}$. The bending strength of the samples was determined using the fourpoint bending test according to ISO 9585:1990. The initial strength of the noncorroded ZEKI00 plate was II\% greater than that of the $\mathrm{MgCa} 0.8$ plate; both were approximately $65 \%$ weaker than a titanium plate. The bending strength was determined after 48 and $96 \mathrm{~h}$ of immersion in Hank's Balanced Salt Solution; both magnesium alloys decreased by approximately $7 \%$ after immersion for $96 \mathrm{~h}$. The degradation rate and the $\mathrm{Mg}^{2+}$ release of ZEKI00 were lower than those of $\mathrm{MgCa}$ 0.8. Strong pitting and filiform corrosion were observed in the $\mathrm{MgCa0} .8$ samples after $96 \mathrm{~h}$ of immersion. The surface of the ZEK 100 plates exhibited only small areas of filiform corrosion. The results of this in vitro study indicate that the ZEK 100 alloy may be more suitable for biomedical applications.
\end{abstract}

Keywords

In vitro, corrosion, magnesium, orthopedic, implants

\section{Introduction}

Magnesium and its alloys were rediscovered at the end of the 20th century as promising degradable biomaterials for orthopedic applications. ${ }^{1-3}$ Researchers are attracted by the prospect of avoiding a second surgery for implant removal, which is necessary with titanium implants. ${ }^{4}$ In addition, magnesium alloys provide desirable mechanical properties, close to those of natural bone, which prevent the "stress shielding" phenomena. 5 Magnesium reportedly stimulates new bone formation (osteoinductive) and also supports the adherence of bone tissue to its surface (osteoconductive) ${ }^{5-8}$

In human body fluids and blood plasma with high $\mathrm{Cl}^{-}$concentrations, the degradation of magnesium alloys is accompanied by a loss of mechanical stability. The resulting surface layer consists mainly of the corrosion product magnesium hydroxide $\left(\mathrm{Mg}(\mathrm{OH})_{2}\right)$, which is locally dissolved into soluble $\mathrm{MgCl}_{2}$. In addition, calcium phosphate salts ${ }^{9}$ and $\mathrm{MgCO}_{3}{ }^{10}$ precipitate on the surface of magnesium alloys resulting in a corrosive protective effect. During the corrosion process, $\mathrm{Mg}^{2+}$ ions are released from the metal.
Magnesium is a natural component of the human body and it is mainly stored in bone $(60-65 \%) .^{11}$ Furthermore, it is the second most abundant cation in cells and an important cofactor for many enzymes that are involved in metabolic pathways and DNA repair processes. $^{11,12}$ The concentration of $\mathrm{Mg}^{2+}$ in the blood serum of human adults comprises $0.7-1.1 \mathrm{~mol} / \mathrm{l}$;

\footnotetext{
'Department of Orthopedic Surgery, Hannover Medical School, Hannover, Germany

${ }^{2}$ CrossBIT, Center for Biocompatibility and Implant-Immunology, Department of Orthopedic Surgery, Hannover Medical School, Hannover, Germany

${ }^{3}$ Institute of Materials Science, Leibniz Universität Hannover, Garbsen, Germany

${ }^{4}$ Department of Crystallography, University of Göttingen, Göttingen, Germany

${ }^{5}$ Institute of Production Engineering and Machine Tools (IFW), Leibniz Universität Hannover, Garbsen, Germany

${ }^{6}$ Small Animal Clinic, University of Veterinary Medicine Hannover,
} Hannover, Germany

Corresponding author:

Andreas Weizbauer, Department of Orthopedic Surgery, Hannover Medical School, Anna-von-Borries-Str. 1-7, Hannover 30625, Germany. Email: weizbauer.andreas@mh-hannover.de 
serum $\mathrm{Mg}^{2+}$ levels exceeding this amount are excreted by the kidneys. ${ }^{11}$

In this in vitro study, two different magnesium alloys were investigated: one containing rare earth elements (REEs) (ZEK100) and MgCa0.8. Both alloys were chosen because of their promising biomechanical properties, and both had been evaluated in vivo in previous studies. ${ }^{13-21}$ ZEK100 pins have shown promising initial mechanical stability. ${ }^{15,20}$ Lensing et al. reported good biocompatibility and an osteoconductive effect of ZEK100 in the middle ear of rabbit. ${ }^{17}$ In contrast, some studies have shown that the biocompatibility of the ZEK100 alloy appears to be questionable. ${ }^{16,22}$

Pure magnesium possesses insufficient mechanical properties. ${ }^{23}$ The alloying of magnesium with a large variety of elements was introduced to solve this issue. These alloying elements influence the corrosion film composition and therefore the corrosion properties. ${ }^{24}$ Magnesium alloyed with passivating elements, such as the REE (yttrium and neodymium), exhibits enhanced corrosion resistance. ${ }^{18,24}$ Magnesium alloys containing REE were first investigated at the beginning of the $1980 \mathrm{s.}^{25}$ The addition of REE contributes to solid solution strengthening and grain boundary strengthening, and therefore enhances the ductility of the alloy. 1,25

Several studies have investigated the properties and corrosion behavior of binary magnesium-calcium alloys. ${ }^{13,14,18,19,26-30}$ The addition of calcium provides solid solution strengthening and contributes to grain refinement owing to grain boundary strengthening. ${ }^{1}$ It was observed that the addition of calcium above the solubility limit of approximately $1.34 \mathrm{wt} \% \mathrm{Ca}$ enhanced the corrosion rate. ${ }^{18,19,26}$ The addition of less than $1 \mathrm{wt} \% \mathrm{Ca}$ demonstrated a low corrosion rate with an appropriate elastic modulus. ${ }^{18}$

Previous studies have demonstrated good biocompatibility of $\mathrm{MgCa} 0.8$ in vivo. ${ }^{13,28}$ The production of high amounts of gas in a short time due to high corrosion rates is undesirable for clinical applications. The accumulation of gas associated with $\mathrm{MgCa} 0.8$ implants was mild to moderate in vivo, with no harmful effects toward the animal. ${ }^{14}$

In this in vitro study, we investigated the corrosion behavior and mechanical properties of two different alloys (MgCa0.8 and ZEK100) in Hank's Balanced Salt Solution (HBSS). The results were compared with a titanium alloy plate (Ti6Al4V) of similar sample size and shape. This study is focused on primary stability and the effects of degradation during the first days of immersion. In addition, $\mathrm{Mg}^{2+}$ release from the alloy was determined, and the corrosion rate was evaluated according to the mass loss method. Alloy surfaces were investigated using scanning electron microscopy (SEM), and high-energy synchrotron radiation was applied for microstructural characterization.

\section{Methods}

\section{Material and preparation}

Two different magnesium alloys were examined in this study: ZEK100 ( $1 \mathrm{wt} \%$ zinc, $0.1 \mathrm{wt} \%$ zirconium, and $0.1 \mathrm{wt} \%$ rare earth metals) and $\mathrm{MgCa} 0.8(0.8 \mathrm{wt} \%$ calcium). The plates were $50 \mathrm{~mm}$ long, $8 \mathrm{~mm}$ wide, and $2 \mathrm{~mm}$ thick. They were manufactured by face slab milling. Five screw holes were drilled and counterbored in each plate. The resulting screw holes had an inner diameter of $3 \mathrm{~mm}$ on the bone-facing side and a counterbore diameter of $5 \mathrm{~mm}$ (Figure 1). The samples had a surface of $898 \mathrm{~mm}^{2}$. Two titanium alloy plates with the same dimensions were manufactured from a Ti6A14V rod (Goodfellow GmbH, Bad Nauheim, Germany).

The surfaces of the magnesium samples were pickled prior to immersion testing with a solution of $5 \mathrm{ml} 65 \%$ nitric acid (Merck, Darmstadt, Germany), $20 \mathrm{ml}$ $85 \%$ glycerol (Merck, Darmstadt, Germany), and $5 \mathrm{ml} \mathrm{100 \%}$ acetic acid (Merck, Darmstadt, Germany) for $30 \mathrm{~s}$. Next, the samples were ultrasonically cleaned for $2 \mathrm{~min}$ with isopropanol and then dried in a vacuum drying oven (Heraeus Vacuum oven, Thermo Scientific, Bonn, Germany) at $50^{\circ} \mathrm{C}$ for approximately $20 \mathrm{~min}$.

\section{Immersion testing}

The static immersion test was performed in HBSS (Biochrom AG, Berlin, Germany) to simulate the normal ion concentration under physiological conditions at $37.5^{\circ} \mathrm{C}$. The corrosion media contained $8.00 \mathrm{~g} / 1 \mathrm{NaCl}, 0.4 \mathrm{~g} / 1 \mathrm{KCl}, 0.04 \mathrm{~g} / 1 \mathrm{Na}_{2} \mathrm{HPO}_{4}, 0.06 \mathrm{~g} / \mathrm{l}$ $\mathrm{KH}_{2} \mathrm{PO}_{4}, \quad 0.20 \mathrm{~g} / 1 \quad \mathrm{MgSO}_{4} \cdot 7 \mathrm{H}_{2} \mathrm{O}, \quad 0.14 \mathrm{~g} / 1 \quad \mathrm{CaCl}_{2}$, $1.00 \mathrm{~g} / 1$ glucose, and $0.35 \mathrm{~g} / 1 \mathrm{NaHCO}_{3}$. The plates were placed into $500 \mathrm{ml}$ HBSS by a nonresorbable

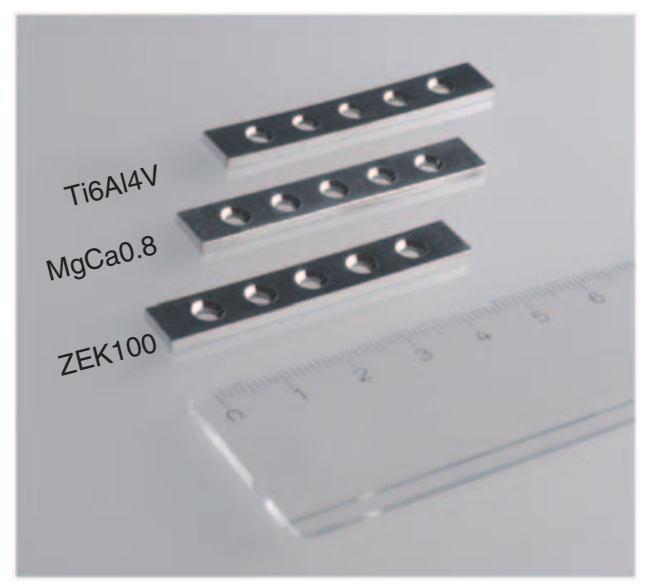

Figure I. Picture of the plates (length: $50 \mathrm{~mm}$, width: $8 \mathrm{~mm}$, thickness: $2 \mathrm{~mm}$ ) used in this in vitro study. 
wire (Ethicon ${ }^{\mathrm{TM}}$ Prolene ${ }^{\mathrm{TM}}$, 4-0, Johnson \& Johnson $\mathrm{GmbH}$, Neuss, Germany). The $\mathrm{pH}$ of the solution was monitored during the immersion test using a $\mathrm{pH}$ meter $\left(\right.$ Schott $^{\circledR}$ Instruments Lab850, SI Analytics $\mathrm{GmbH}$, Mainz, Germany). After immersion, the samples were dried and the corrosion layer was removed with chromic acid. Two samples were used per interval of each magnesium alloy. The degradation rate was evaluated according to the weight loss method ${ }^{31}$

$$
\Delta \mathrm{W}=\frac{W_{\text {before }}-W_{\text {after }}}{A t}
$$

where $\Delta \mathrm{W}$ is the weight loss, $W_{\text {before }}(\mathrm{mg})$ is the weight of each sample before corrosion, and $W_{\text {after }}(\mathrm{mg})$ is the weight of each sample after corrosion. $A$ is defined as the sample's surface area $\left(\mathrm{cm}^{2}\right)$ and $t$ is the immersion time (d). This weight loss rate was converted into an average corrosion rate $(\mathrm{mm} / \mathrm{y})$ using $^{31,32}$

$$
\mathrm{P}_{\mathrm{W}}=2.1 \Delta \mathrm{W}
$$

\section{Detection of $\mathrm{Mg}^{2+}$ release through inductively coupled plasma optical emission spectroscopy (ICP-OES)}

The ICP-OES (Spectro Ciros Vision EOP, Spectro Analytical Instruments, Kleve, Germany) was applied to quantitatively determine the release of magnesium ions from the plates during the corrosion process. Two plates of each alloy were immersed in $100 \mathrm{ml}$ HBSS at $37^{\circ} \mathrm{C}$ for $158 \mathrm{~h}$. At fixed time intervals (the first after $45 \mathrm{~min}$ ), $1 \mathrm{ml}$ was taken for analysis and replaced with the same amount of fresh corrosion media. The $\mathrm{pH}$ of every analysis sample was monitored.

\section{Biomechanical testing}

To specify the mechanical properties of the specimens, they were tested according to ISO 9585:1990. The fourpoint bending test setup (Figure 2) was designed for tests with a uniaxial material testing machine (Mini Bionix 858, MTS Systems in Minneapolis, MN, USA). The test system consisted of four rollers with a diameter of $8 \mathrm{~mm}$. The distance between the lower and outer rollers was $32 \mathrm{~mm}$, and the distance between the upper and inner rollers was $10 \mathrm{~mm}$. The plates were positioned on the lower rollers according to the protocol of ISO 9585:1990. The distance between the outer and inner rollers was $11 \mathrm{~mm}$, including a screw hole of the demonstrators. The central screw hole and another screw hole were positioned between the inner rollers. The test rig was produced by the Research Workshop of the Medical School, Hannover, Germany.

\section{Microstructural characterization}

After the corrosion products were removed from the surface with chromic acid, the magnesium plates were analyzed with a Zeiss EVO 60 VP SEM.

Diffraction experiments were performed using highenergy synchrotron radiation $(\mathrm{E} \sim 100 \mathrm{keV}$, $\lambda=0.12561 \AA$ ). A Perkin-Elmer area detector $(400 \mathrm{~mm} \times 400 \mathrm{~mm}, 200 \mu \mathrm{m}$ pixel size) was used with a sample-detector distance of $1430 \mathrm{~mm}$.

\section{Results}

\section{Immersion test and corrosion properties}

The $\mathrm{pH}$ of HBSS was measured during the immersion of the plates (Figure 3). The $\mathrm{pH}$ of the HBSS increased rapidly during the first hours of exposure. After $12 \mathrm{~h}$ of
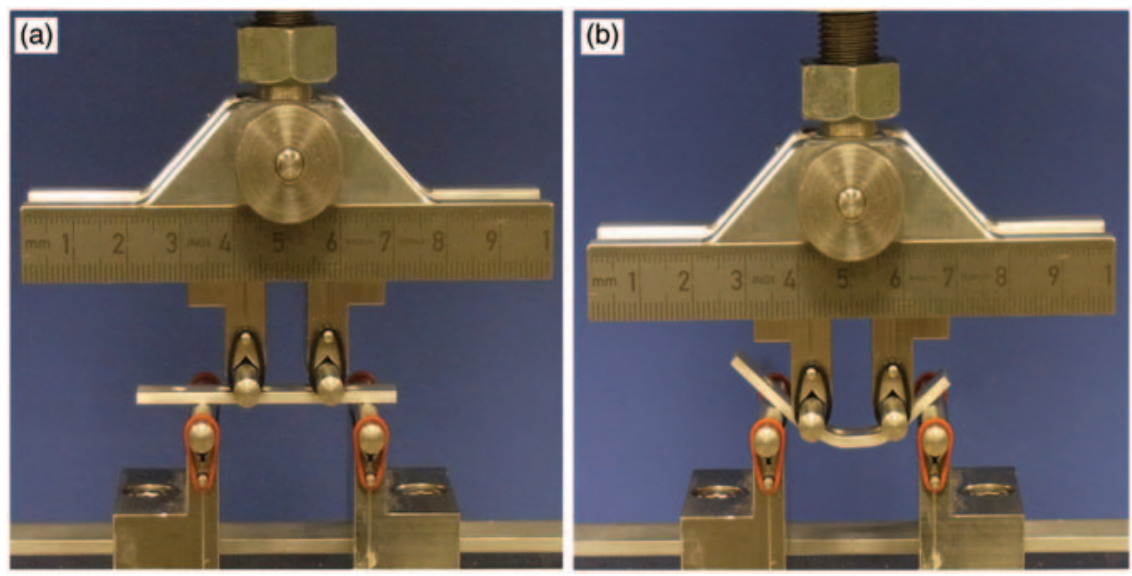

Figure 2. Picture of the four-point bending setup. The samples were tested according to ISO 9585:1990. 


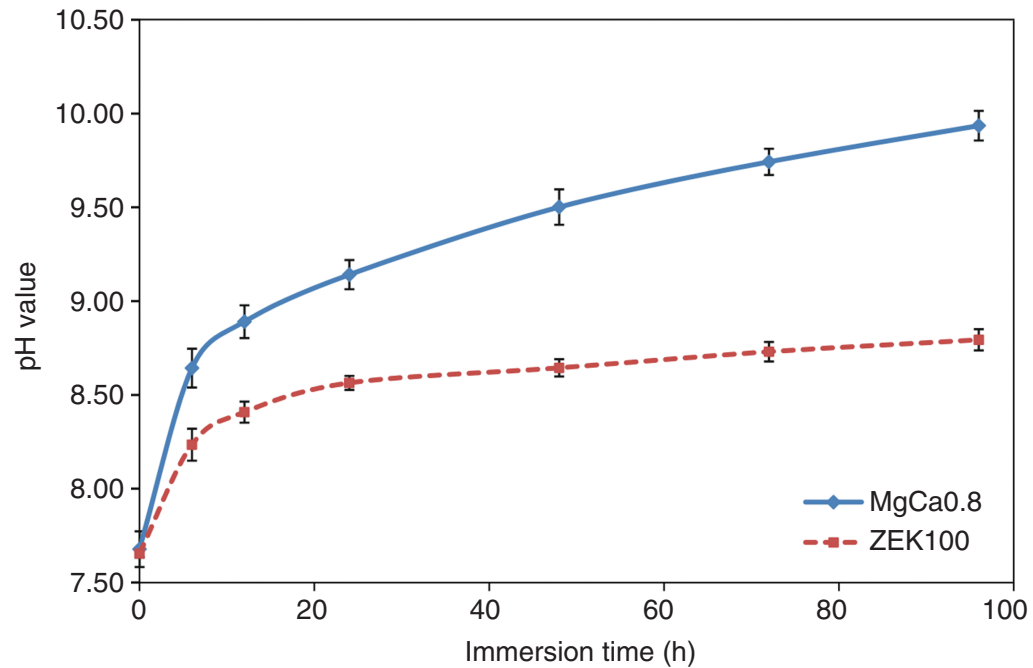

Figure 3. $\mathrm{pH}$ value versus immersion time of $\mathrm{MgCa} 0.8$ and $\mathrm{ZEK} \mathrm{I} 00$ plates in $500 \mathrm{ml}$ Hank's solution. The dots represent mean values and standard deviation. Sample size for each alloy: $n=4$ for $0-48 h, n=2$ each for 72 and $96 \mathrm{~h}$.

Table I. Corrosion rates of the magnesium alloy plates according to the mass loss method. ${ }^{31}$ Sample size: Two of each alloy per interval.

\begin{tabular}{lll}
\hline & \multicolumn{2}{l}{ Mean corrosion rate $(\mathrm{mm} / \mathrm{y})$} \\
\cline { 2 - 3 } & $48 \mathrm{~h}$ immersion & $96 \mathrm{~h}$ immersion \\
\hline MgCa0.8 & 3.62 & 2.89 \\
ZEKI00 & 0.70 & 0.63 \\
\hline
\end{tabular}

immersion, the alkalization of the corrosion medium progressed at a slower pace. However, the immersion of $\mathrm{MgCa} 0.8$ plates resulted in a higher HBSS $\mathrm{pH}$ than the immersion of ZEK 100 plates. After $96 \mathrm{~h}$ of immersion, the $\mathrm{pH}$ of HBSS rose to 9.9 for $\mathrm{MgCa} 0.8$ plates compared with 8.8 for ZEK100 plates.

The corrosion rate was determined after 48 and $96 \mathrm{~h}$ using the weight loss method (Table 1). ZEK100 demonstrated a five-fold lower corrosion rate than $\mathrm{MgCa} 0.8$.

\section{Release of $\mathrm{Mg}^{2+}$ from the magnesium plates}

The $\mathrm{Mg}^{2+}$ concentration dissolved into the HBSS from the magnesium samples was determined using ICP-OES (Figure 4(a)). The $\mathrm{MgCa} 0.8$ plates exhibited rapid $\mathrm{Mg}^{2+}$ release during the first $20 \mathrm{~h}$ of immersion. The ZEK100 plates exhibited a more consistent increase of $\mathrm{Mg}^{2+}$ concentration throughout the exposure time. The rate of $\mathrm{Mg}^{2+}$ release from the $\mathrm{MgCa} 0.8$ plates during the first $24 \mathrm{~h}$ of immersion was $1.082 \mathrm{mg} / \mathrm{h}(1.2 \times$ $10^{-3} \mathrm{mg} / \mathrm{h} \mathrm{mm}^{2}$ ), nearly eight-fold higher than the rate of ion release from the ZEK100 plates: $0.143 \mathrm{mg} / \mathrm{h}$ $\left(1.592 \times 10^{-4} \mathrm{mg} / \mathrm{h} \mathrm{mm}^{2}\right)$ (Figure 4(b)). Moreover, the $\mathrm{pH}$ of HBSS increased more rapidly as a result of the immersion of the $\mathrm{MgCa} 0.8$ samples than the ZEK 100 samples. After $20 \mathrm{~h}$, the $\mathrm{MgCa} 0.8$ corrosion media reached a stable $\mathrm{pH}$ of approximately 10 (Figure 4(c)).

\section{The effect of corrosion on bending strength}

Figure 5 shows the bending strengths of the magnesium and titanium plates. Uncorroded samples of ZEK 100 $(0.306 \pm 0.003 \mathrm{Nm})$ were stronger than $\mathrm{MgCa} 0.8$ $(0.272 \pm 0.00005 \mathrm{Nm})$. In contrast, the bending strength of titanium plates with the same dimensions was higher $(0.803 \pm 0.001 \mathrm{~N} \mathrm{~m})$.

The strength of both magnesium alloys decreased with immersion time. The bending strength after $96 \mathrm{~h}$ of immersion was approximately $7 \%$ lower than the initial bending strength $(0 \mathrm{~h}$ immersion $)$.

\section{Microstructural characterization and phase identification}

Figure 6 shows the surface of the magnesium plates after removal of the surface corrosion products that resulted from $96 \mathrm{~h}$ of immersion. Filiform and pitting corrosion were observed on the surface of the $\mathrm{MgCa} 0.8$ alloy. The surface of the ZEK100 plates showed only small areas of filiform corrosion (Figure 6(a) and (b)).

The diffraction diagram and the diffraction rings of both alloys are displayed in Figure 7 . The diffraction rings of both alloys demonstrated an inhomogeneous intensity distribution (Figure 7(b) and (e)). The diffraction diagram of the $\mathrm{MgCa} 0.8$ alloy is shown in Figure 7(c) and (d). In addition to the measured intensities 

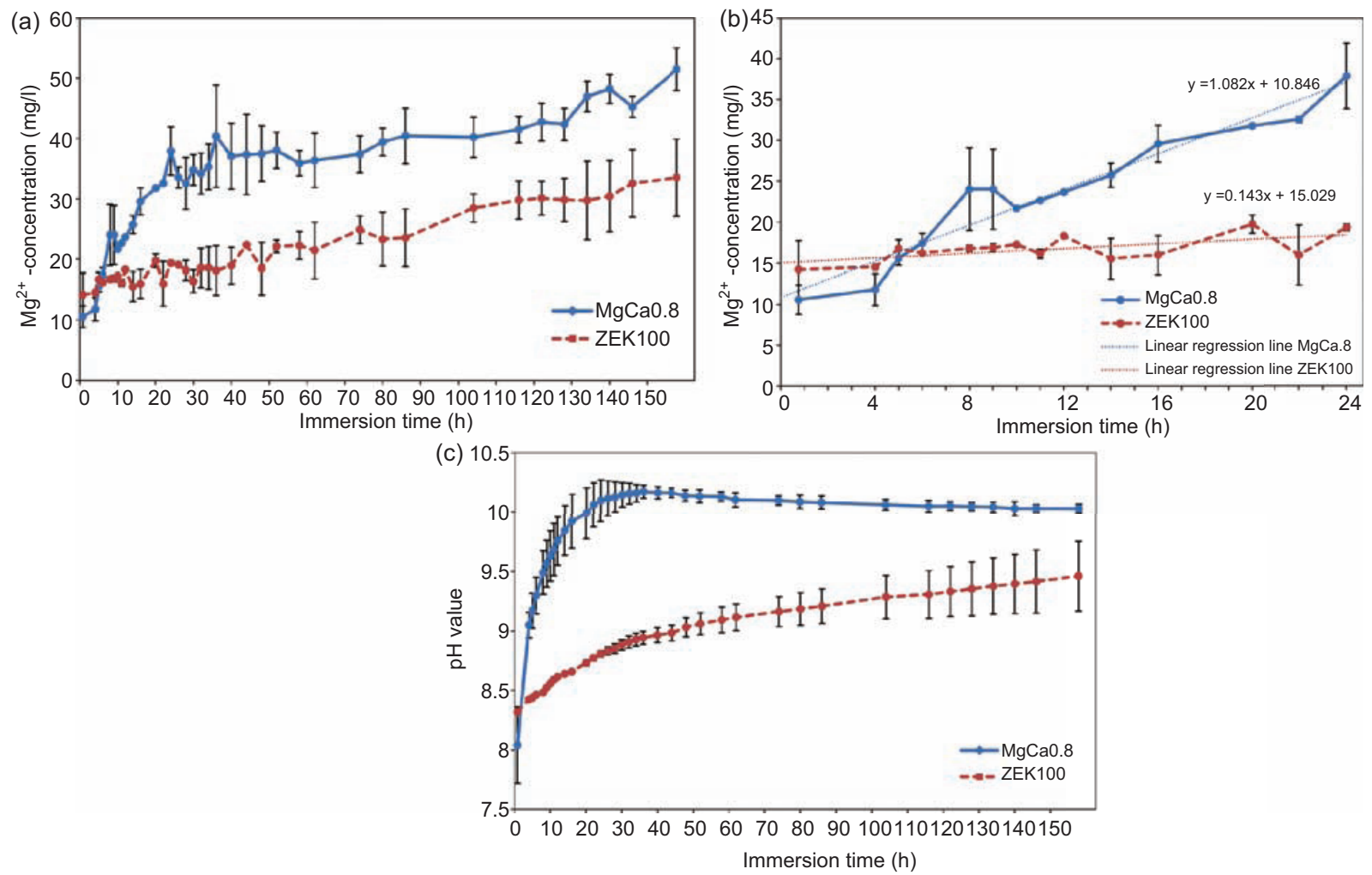

Figure 4. (a) $\mathrm{Mg}^{2+}$ release from the ZEKIOO and $\mathrm{MgCaO} 0.8$ plates as a function of time. (b) Average $\mathrm{Mg}^{2+}$ release during the first $24 \mathrm{~h}$. (c) $\mathrm{pH}$ of the analyzed corrosion media sample. The dots represent mean values and standard deviation. Two samples were tested per alloy.

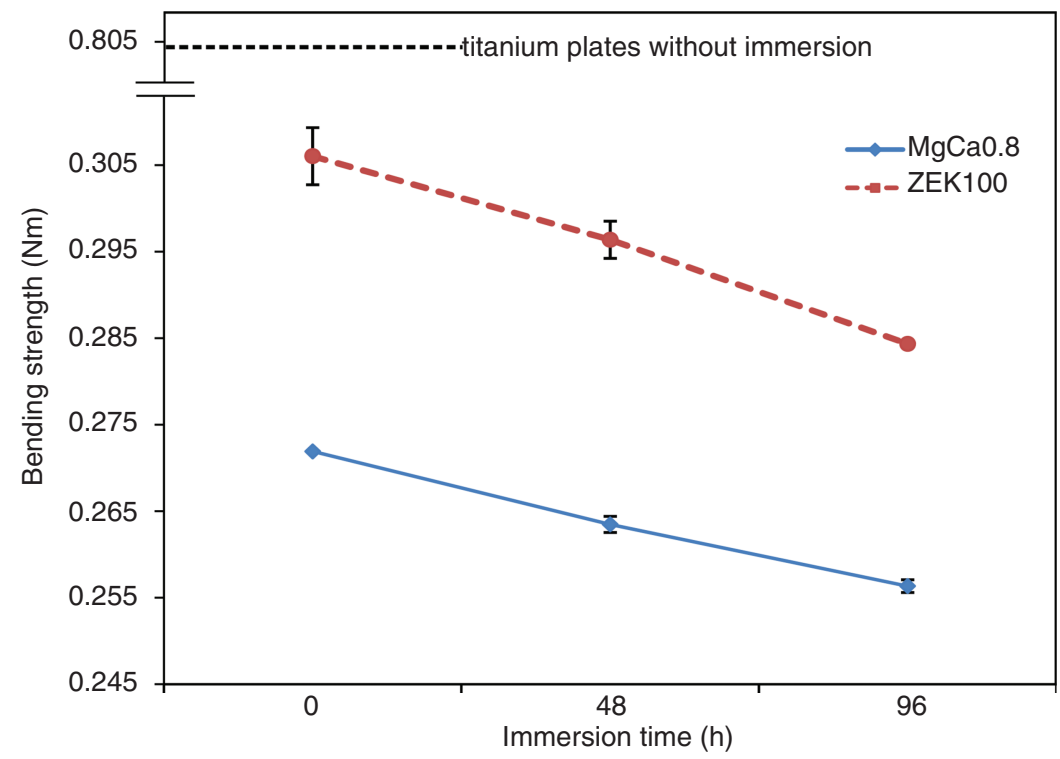

Figure 5. Bending strength versus immersion time. The bending strength of both alloys decreased with immersion time. The dots represent mean values and standard deviation. Two samples were tested per alloy and immersion time.

(black line), simulated diffraction diagrams are also provided for $\mathrm{Mg}$ (solid solution, red line) and $\mathrm{Mg}_{2} \mathrm{Ca}$ (intermetallic compound, blue line). Both simulated phases fit the position of the measured reflection lines quite well, but not the intensity. The measured intensities of the ZEK100 samples also differed strongly because of the material's texture. No intermetallic phases were detected. 

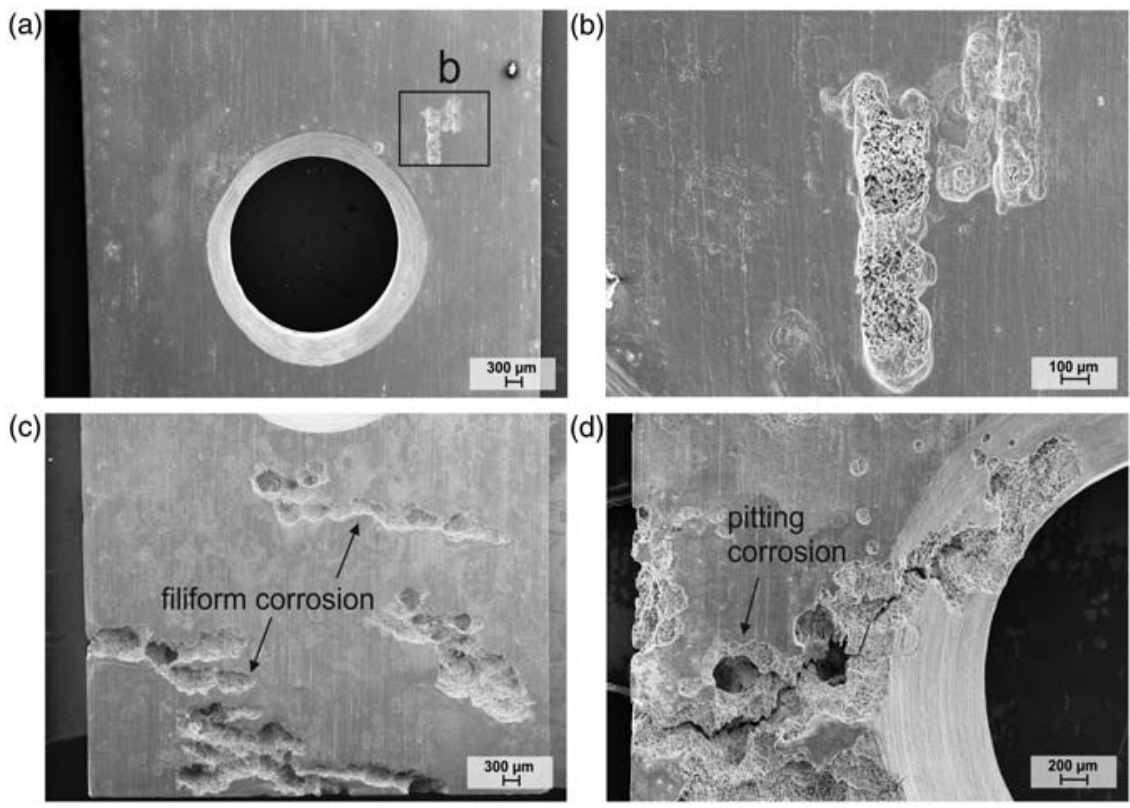

Figure 6. SEM pictures of the plates after $96 \mathrm{~h}$ immersion and removal of the corrosion layer. (a) and (b): ZEKI00 and (c) and (d): $\mathrm{MgCa} 0.8$.
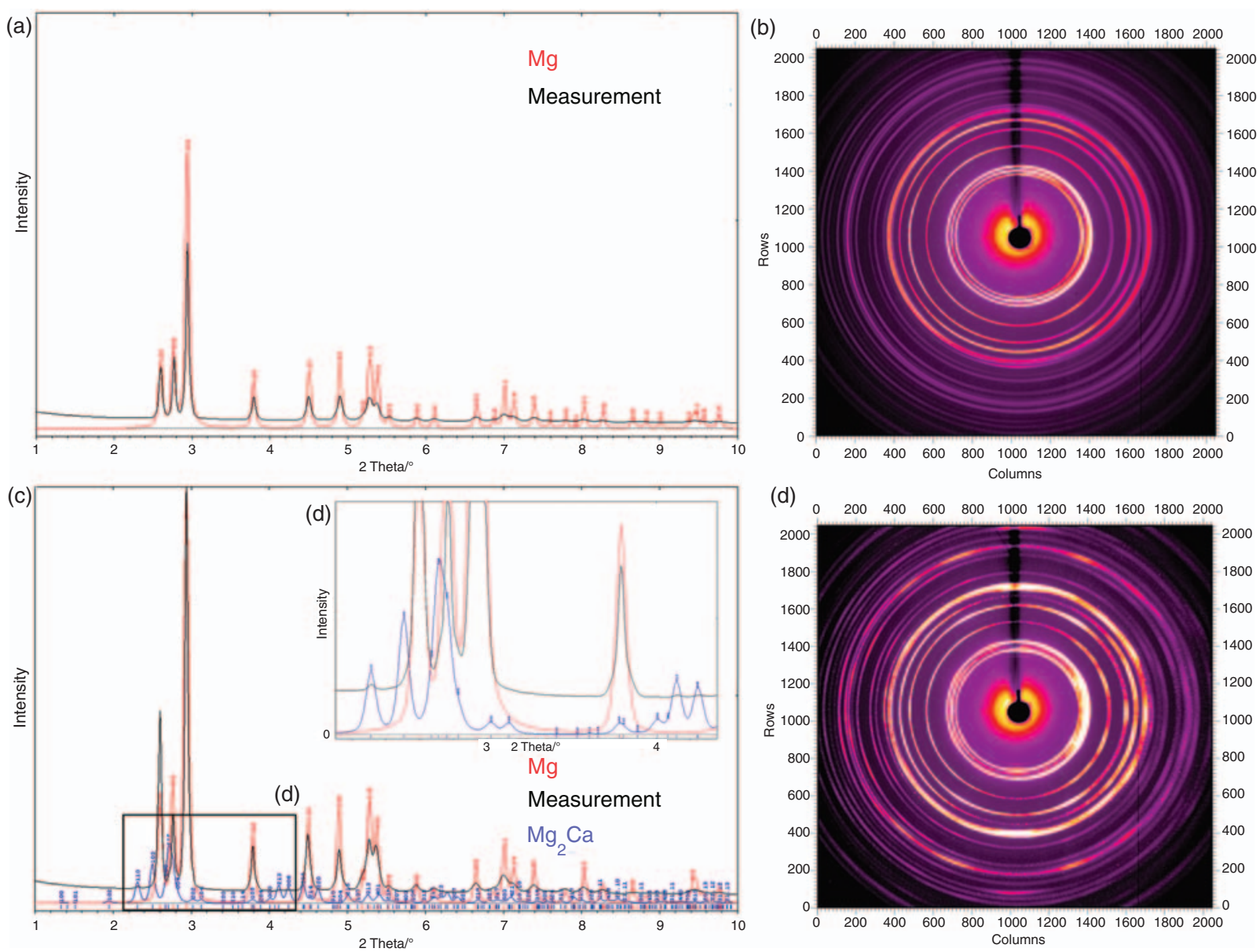

Figure 7. Diffraction diagram and diffraction rings of ZEKIOO and $\mathrm{Mg}_{2} \mathrm{Ca} 0.8$ alloy samples. (a) and (b): ZEKI00 and (c) to (e): $\mathrm{Mg}_{2} \mathrm{Ca} 0.8$. 


\section{Discussion}

Fracture healing is dependent on the fracture gap and achieved stabilization. Plates are a common orthopedic implant and are usually attached to the bone with screws. ${ }^{33}$ The fixation of a plate should supply sufficient stability to enhance fracture healing. High primary stability is important and should not decrease greatly during the first days after the placement of the plate. Therefore, in this in vitro study we focused on the initial strength of the magnesium implants versus titanium implants and investigated the implant stability specifically during the first days of immersion. The currently used plates are made of stainless steel or titanium alloys $^{5}$ and are available in a wide range of sizes. In this study, five-hole plates from two different magnesium alloys were examined after immersion in HBSS and compared with titanium plates.

The biomechanical results of the magnesium-based plates were compared with those of a plate made from the titanium alloy Ti6Al4V, which is commonly used in orthopedic trauma surgery. Titanium alloys exhibit minor biocorrosion with the release of metallic ions, which normally do not compromise plate stability. ${ }^{34}$ The corrosion products, released metallic ions, have been associated with proinflammatory, cytokineinduced, enhanced osteoclastic activity, which in turn causes bone resorption. ${ }^{34}$

We assume that the loss of stability of titanium alloys is negligible within the short period of time (96h) observed in our study. Therefore, the biomechanical examinations of the titanium plates were performed to their initial conditions without immersion tests.

The bending strength of the titanium plates is comparable to that of a $2 \mathrm{~mm}$ mini-fragment plate, which was also tested according to ISO $9585: 1990 .{ }^{35}$ In this study a bending strength of $0.53 \mathrm{Nm}$ was determined. The biomechanical parameter of the tested $2 \mathrm{~mm}$ minifragment plate is lower than the bending strength of the titanium plates evaluated in our study $(0.803 \mathrm{Nm})$. The reason for this slight deviation might be explained by the difference in plate design.

The initial strengths of both magnesium alloys were approximately $65 \%$ lower than that of the titanium alloy. Of the two magnesium alloys, the ZEK100 plates exhibited greater initial stability. Therefore, ZEK100 plates may be considered more suitable for osteosynthesis applications than $\mathrm{MgCa} 0.8$ plates. The degradation of magnesium alloys is known to be high in the first hours of exposure to the corrosion media. This is mainly due to the fact that the corrosion protective layer needs some time for formation. Therefore, we particularly investigated the first hours of corrosion and its effect on the stability of the magnesium plates.
The study of Waizy et al. showed that between week 2 and week 6 of immersion of ZEK100 in HBSS no considerable change in bending strength was reported. ${ }^{36}$ Our study showed that in the first $96 \mathrm{~h}$ of degradation the bending strength of both magnesium alloys decreased about 7\%. ZEK100 still have a higher stability and is therefore based on the biomechanical results of the preferred magnesium alloy. Many studies have shown that the degradation of magnesium alloys in in vitro experiments is higher than in comparable in vivo studies. ${ }^{37-39}$ A decreased loss of stability in vivo compared to the results in this study is assumed.

Alloy plates are used in clinical practice as internal splints to hold fractured ends of bone together; additional fracture stabilization with lag screws is common. According to the biomechanical results, the preferred use of these magnesium-based plates is the fixation of non-weight-bearing bones (e.g. fracture of the metacarpal bones). Sufficient stability of degradable plates in vivo must be ensured during the first 6-8 weeks after implantation. ${ }^{40}$

The magnesium alloy ZEK100 contains REE and zirconium in low concentrations. The alloying elements are used to improve the mechanical and corrosion properties of the biomaterial. ${ }^{41}$ These alloying elements are known to have adverse effects and potential longterm risks, ${ }^{42-45}$ although some studies have reported good biocompatibility. ${ }^{46,47}$ Allergic hypersensitivity, reduction of hemoglobin oxygen affinity, and fatty liver are some potential adverse effects of these elements at toxic doses. ${ }^{43,45}$ Chelated REE are easily excreted in the urine, and mortality studies have revealed that REE are not highly toxic. ${ }^{43}$ However, bone is one of the main target organs of REE because REE are of a radius similar to $\mathrm{Ca}^{2+}$ ions, which may lead to $\mathrm{REE}$ accumulation in the environment directly surrounding the implant. ${ }^{43}$ Because implants made of degradable magnesium alloys are not removed after implantation, in vivo biocompatibility studies should focus on the long-term effects of these implants. In an animal study with 12 months of observation time, a good biological response to a REE-containing alloy (MgYREZr, similar to WE43) and its degradation products was observed. ${ }^{48}$

The degradation of magnesium and its alloys in biofluids is described by the following reaction

Anodic reaction: $\mathrm{Mg} \rightarrow \mathrm{Mg}^{2+}+2 \mathrm{e}^{-}$

Cathodic reaction: $2 \mathrm{H}_{2} \mathrm{O}+2 \mathrm{e}^{-} \rightarrow \mathrm{H}_{2} \uparrow+2 \mathrm{OH}^{-}$

$$
\mathrm{Mg}^{2+}+2 \mathrm{OH}^{-} \rightarrow \mathrm{Mg}(\mathrm{OH})_{2}(\mathrm{~s})
$$

Degradation is accompanied by an alkalization of the corrosion media due to the production of hydroxide ions $\left(\mathrm{OH}^{-}\right)$. These experiments were performed without $\mathrm{CO}_{2}$ gas application. $\mathrm{HCO}_{3}{ }^{-} / \mathrm{CO}_{2}$ is the main buffering 
system in blood and in HBSS. The high proportion of hydroxide ions supports the formation of magnesium hydroxide, which in turn acts as a protective layer against corrosion. The greater tendency toward film formation is reportedly associated with local $\mathrm{pH}>10.5$ and is believed to have a corrosion-inhibiting effect. ${ }^{49}$ Magnesium hydroxide is disrupted by chloride ions with the release of $\mathrm{OH}^{-}$

$$
\mathrm{Mg}(\mathrm{OH})_{2}+2 \mathrm{Cl}^{-} \rightarrow \mathrm{MgCl}_{2}+2 \mathrm{OH}^{-}
$$

In response to the immersion of both magnesium alloys (ZEK100 and $\mathrm{MgCa} 0.8$ ), the $\mathrm{pH}$ of the HBSS increased sharply during the first hours of exposure. An accelerated $\mathrm{pH}$ increase during the first hours of immersion was reported by several in vitro studies. ${ }^{50-53}$ The decelerated increase of $\mathrm{pH}$ after $6 \mathrm{~h}$ may be attributed to the formation of magnesium hydroxide and other phosphate- and calcium-containing salts, which precipitated on the surface of the magnesium samples. Interestingly, the $\mathrm{pH}$ of the HBSS increased more with the immersion of $\mathrm{MgCa} 0.8$ plates than ZEK100 plates. This finding indicated the more progressed and faster corrosion of the $\mathrm{MgCa} 0.8$ plates. These observations were supported by the determined corrosion rates for both magnesium alloys according to the mass loss method (Table 1). The corrosion rates were approximately five-fold greater for the $\mathrm{MgCa} 0.8$ plates than for the ZEK100 plates. The corrosion rate was slower after $96 \mathrm{~h}$ of immersion than after $48 \mathrm{~h}$, which can be explained by the protective effect of the formed surface films (resulting from the precipitation of calcium phosphate salts and magnesium hydroxide). Song et al. reported the formation of a magnesium hydroxide film on the surface of an AZ31 within $2 \mathrm{~h}$ after immersion. ${ }^{23}$ Similar to our results, Zhu et al. reported a reduction of the corrosion rate with progressing immersion time for a AZ31 alloy. ${ }^{54}$ A study by Walker et al. reported lower corrosion rates for $\mathrm{MgCa} 0.8$ than were observed in the present study $(1.937 \mathrm{~mm} / \mathrm{y}$ in MEMp, $1.291 \mathrm{~mm} / \mathrm{y}$ in MEM, and $0.795 \mathrm{~mm} / \mathrm{y}$ in EBSS). ${ }^{38}$

Several studies have shown that the corrosion rates in vivo differ from those determined in vitro. ${ }^{39,55}$ Many different parameters influence the in vitro corrosion rate (e.g. choice of corrosion media, temperature, $\mathrm{CO}_{2}$ gas application, etc.). ${ }^{3,56,57}$ Therefore, the alteration of parameters makes it difficult to compare different in vitro tests.

The release of $\mathrm{Mg}^{2+}$ from the metal was measured using ICP-OES analysis (Figure 4). Only a few studies have analyzed the release of $\mathrm{Mg}^{2+}$ from magnesium alloys. ${ }^{51,52}$ These results confirm the observations of the immersion test and the determination of the corrosion rate. The release of $\mathrm{Mg}^{2+}$ decelerates with immersion time as a consequence of protective surface layer formation. This analysis is influenced by the formation and degradation of $\mathrm{Mg}(\mathrm{OH})_{2}$. Some of the dissolved $\mathrm{Mg}^{2+}$ ions from the metal form insoluble magnesium hydroxide $\mathrm{Mg}(\mathrm{OH})_{2}$, and therefore are excluded from the analysis, although as mentioned previously, $\mathrm{Mg}(\mathrm{OH})_{2}$ can be transformed into soluble $\mathrm{MgCl}_{2}$ by $\mathrm{Cl}^{-}$ions and is therefore again accessible for ICPOES analysis. However, the speed of this accumulation and degradation process is unknown. Notably, the high rate of $\mathrm{MgCa} 0.8$ corrosion appears to result in a faster loss of biomechanical stability.

The microstructural characterization of the $\mathrm{MgCa} 0.8$ plates revealed the presence of the intermetallic $\mathrm{Mg}_{2} \mathrm{Ca}$ phase, which is consistent with other studies. ${ }^{26,58}$ Intermetallic phases form during the solidification of the cast alloys and mainly distribute at the grain boundaries. ${ }^{59}$ Most of the intermetallic second phases reportedly possess a corrosion-accelerating effect. $^{60}$ This reduction of corrosion resistance is mainly attributed to galvanic corrosion between the anodic $\alpha-\mathrm{Mg}$ and the intermetallic phases, which act as a cathode. ${ }^{60}$ Kirkland et al. report that this phase is very reactive, with faster dissolution rates than $\mathrm{Mg}{ }^{26}$ The $\mathrm{Mg}_{2} \mathrm{Ca}$ phase is described as a more efficient anode than $\alpha-\mathrm{Mg}^{26}$

Analysis of the ZEK100 plate revealed no intermetallic phases. Here, a combined Rietveld texture analysis would have given very precisely the amounts of the present phases and the texture (to calculate the anisotropic behavior of the material). Small amounts of other phases might also be found using this method, because of the improved alignment of the measured intensities. $\mathrm{MgZn}$ and $\mathrm{Mg}_{2} \mathrm{Zn}$ are the most prominent intermetallic phases that would be expected according to an analysis of a similar magnesium alloy. ${ }^{51,61}$

\section{Conclusion}

Magnesium plates made of different magnesium alloys were investigated after in vitro corrosion in HBSS. Biomechanical tests demonstrated a continuous loss of mechanical strength by osteosynthesis plates made of magnesium alloys. Although the initial bending strength of the uncorroded ZEK100 plate was greater than that of the $\mathrm{MgCa} 0.8$ plate, both were approximately $65 \%$ weaker than a titanium plate. The degradation rate and the $\mathrm{Mg}^{2+}$ release of ZEK100 were lower than those of $\mathrm{MgCa} 0.8$.

\section{Acknowledgments}

The authors gratefully acknowledge the financial support provided by the German Research Society (DFG) within the collaborative research project (SFB 599). We thank Markus Badenhop for excellent technical support and Christopher Müller for the design of Figure 1. 


\section{References}

1. Witte F, Hort N, Vogt C, et al. Degradable biomaterials based on magnesium corrosion. Curr Opin Solid State Mater Sci 2008; 12(5-6): 63-72.

2. Witte F. The history of biodegradable magnesium implants: A review. Acta Biomater 2010; 6(5): 1680-1692.

3. Waizy H, Seitz J-M, Reifenrath J, et al. Biodegradable magnesium implants for orthopedic applications. $J$ Mater Sci 2013; 48(1): 39-50.

4. Yang L, Huang Y, Peng Q, et al. Mechanical and corrosion properties of binary Mg-Dy alloys for medical applications. Mater Sci Eng B 2011; 176(20): 1827-1834.

5. Staiger MP, Pietak AM, Huadmai J, et al. Magnesium and its alloys as orthopedic biomaterials: A review. Biomaterials 2006; 27(9): 1728-1734.

6. Albrektsson T and Johansson C. Osteoinduction, osteoconduction and osseointegration. Eur Spine J 2001; 10(Suppl 2): 96-101.

7. Xu L, Yu G, Zhang E, et al. In vivo corrosion behavior of $\mathrm{Mg}-\mathrm{Mn}-\mathrm{Zn}$ alloy for bone implant application. J Biomed Mater Res A 2007; 83(3): 703-711.

8. Zreiqat H, Howlett CR, Zannettino A, et al. Mechanisms of magnesium-stimulated adhesion of osteoblastic cells to commonly used orthopaedic implants. J Biomed Mater Res 2002; 62(2): 175-184.

9. Rettig R and Virtanen S. Composition of corrosion layers on a magnesium rare-earth alloy in simulated body fluids. J Biomed Mater Res A 2009; 88(2): 359-369.

10. Willumeit R, Fischer J, Feyerabend F, et al. Chemical surface alteration of biodegradable magnesium exposed to corrosion media. Acta Biomater 2011; 7(6): 2704-2715.

11. Vormann J. Magnesium: Nutrition and metabolism. Mol Aspects Med 2003; 24(1-3): 27-37.

12. Hartwig A. Role of magnesium in genomic stability. Mutat Res 2001; 475(1-2): 113-121.

13. Erdmann N, Bondarenko A, Hewicker-Trautwein M, et al. Evaluation of the soft tissue biocompatibility of $\mathrm{MgCa} 0.8$ and surgical steel $316 \mathrm{~L}$ in vivo: A comparative study in rabbits. Biomed Eng Online 2010; 9: 63.

14. Erdmann N, Angrisani N, Reifenrath J, et al. Biomechanical testing and degradation analysis of MgCa0.8 alloy screws: A comparative in vivo study in rabbits. Acta Biomater 2011; 7(3): 1421-1428.

15. Huehnerschulte TA, Angrisani N, Rittershaus D, et al. In vivo corrosion of two novel magnesium alloys ZEK100 and AX30 and their mechanical suitability as biodegradable implants. Materials 2011; 4(6): 1144-1167.

16. Huehnerschulte TA, Reifenrath J, von Rechenberg B, et al. In vivo assessment of the host reactions of the biodegradation of the two novel magnesium alloys ZEK100 and AX30 in an animal model. Biomed Eng Online 2012; 11: 14.

17. Lensing R, Behrens $P$, Müller PP, et al. In vivo testing of a bioabsorbable magnesium alloy serving as total ossicular replacement prostheses. J Biomater Appl. Epub ahead of print 2013. DOI: 10.1177/0885328212472246.
18. Li Y, Hodgson PD and Wen C. The effects of calcium and yttrium additions on the microstructure, mechanical properties and biocompatibility of biodegradable magnesium alloys. J Mater Sci 2011; 46(2): 365-371.

19. Li Z, Gu X, Lou S, et al. The development of binary Mg$\mathrm{Ca}$ alloys for use as biodegradable materials within bone. Biomaterials 2008; 29(10): 1329-1344.

20. Reifenrath J, Bormann D and Meyer-Lindenberg A. Magnesium alloys as promising degradable implant materials in orthopaedic research. In: Czerwinski F (ed.) Magnesium alloys-corrosion and surface treatments. Rijeka: Intech, 2011, pp.93-108.

21. von der Höh N, Bormann D, Lucas A, et al. Influence of different surface machining treatments of resorbable magnesium alloy implants on degradation-EDX-analysis and histology results. Materwiss Werkst 2009; 40(1-2): 88-93.

22. Dziuba D, Meyer-Lindenberg A, Seitz JM, et al. Longterm in vivo degradation behaviour and biocompatibility of the magnesium alloy ZEK100 for use as a biodegradable bone implant. Acta Biomater. Epub ahead of print 2012. DOI: 10.1016/j.actbio.2012.08.028.

23. Song Y, Shan D, Chen R, et al. Biodegradable behaviors of AZ31 magnesium alloy in simulated body fluid. Mater Sci Eng C 2009; 29(3): 1039-1045.

24. Song $G$ and Atrens A. Understanding magnesium corrosion - a framework for improved alloy performance. $A d v$ Eng Mater 2003; 5(12): 837-858.

25. Al-Samman T and Li X. Sheet texture modification in magnesium-based alloys by selective rare earth alloying. Mater Sci Eng A 2011; 528(10-11): 3809-3822.

26. Kirkland NT, Birbilis N, Walker J, et al. In-vitro dissolution of magnesium-calcium binary alloys: Clarifying the unique role of calcium additions in bioresorbable magnesium implant alloys. $J$ Biomed Mater Res B Appl Biomater 2010; 95(1): 91-100.

27. Krause A, von der Höh N, Bormann N, et al. Degradation behaviour and mechanical properties of magnesium implants in rabbit tibiae. J Mater Sci 2010; 45(3): 624-632.

28. Thomann M, Krause C, Bormann D, et al. Comparison of the resorbable magnesium alloys LAE442 and $\mathrm{MgCa} 0.8$ concerning their mechanical properties, their progress of degradation and the bone-implant-contact after 12 months implantation duration in a rabbit model. Materwiss Werkst 2009; 40(1-2): 82-87.

29. von der Höh N, Bormann D, Lucas A, et al. Influence of different surface machining treatments of magnesiumbased resorbable implants on the degradation behavior in rabbits. Adv Eng Mater 2009; 11(5): B47-B54.

30. Wan Y, Xiong G, Luo H, et al. Preparation and characterization of a new biomedical magnesium-calcium alloy. Mater Design 2008; 29(10): 2034-2037.

31. Zainal Abidin NI, Atrens AD, Martin D, et al. Corrosion of high purity $\mathrm{Mg}, \mathrm{Mg} 2 \mathrm{Zn} 0.2 \mathrm{Mn}, \mathrm{ZE} 41$ and AZ91 in Hank's solution. Corros Sci 2011; 53(3): 862-872.

32. Shi Z, Liu M and Atrens A. Measurement of the corrosion rate of magnesium alloys using Tafel extrapolation. Corros Sci 2010; 52(2): 579-588. 
33. Bartel DL, Davy DT and Keaveny TM. Orthopaedic biomechanics: Mechanics and design in musculosceletal systems. Englewood Cliffs, NJ: Prentice Hall, 2006.

34. Cadosch D, Chan E, Gautschi OP, et al. Metal is not inert: Role of metal ions released by biocorrosion in aseptic loosening - current concepts. J Biomed Mater Res A 2009; 91(4): 1252-1262.

35. Cesarone DM and Disegi JA. Techniques in the application of ISO 9585 test method for the determination of bone plate bending properties. In: Harvey JP and Games RF (eds) Clinical and laboratory performance of bone plates. West Conshohocken, PA: ASTM International, 1994, pp.65-71.

36. Waizy H, Weizbauer A, Modrejewski C, et al. In vitro corrosion of ZEK100 plates in Hank's balanced salt solution. Biomed Eng Online 2012; 11: 12.

37. Mueller W-D, Nascimento ML and Lorenzo de Mele MF. Critical discussion of the results from different corrosion studies of $\mathrm{Mg}$ and $\mathrm{Mg}$ alloys for biomaterial applications. Acta Biomater 2010; 6(5): 1749-1755.

38. Walker J, Shadanbaz S, Kirkland NT, et al. Magnesium alloys: Predicting in vivo corrosion with in vitro immersion testing. J Biomed Mater Res B Appl Biomater 2012; 100(4): 1134-1141.

39. Witte F, Fischer $\mathbf{J}$, Nellesen $\mathbf{J}$, et al. In vitro and in vivo corrosion measurements of magnesium alloys. Biomaterials 2006; 27(7): 1013-1018.

40. Baumgaertel F, Buhl M and Rahn BA. Fracture healing in biological plate osteosynthesis. Injury 1998; 29(Suppl 3): $\mathrm{C} 3-\mathrm{C} 6$.

41. Gu XN and Zheng YF. A review on magnesium alloys as biodegradable materials. Front Mater Sci China 2010; 4(2): 111-115.

42. Haley TJ. Pharmacology and toxicology of the rare earth elements. J Pharm Sci 1965; 54(5): 663-670.

43. Hirano S and Suzuki KT. Exposure, metabolism, and toxicity of rare earths and related compounds. Environ Health Perspect 1996; 104(Suppl 1): 85-95.

44. Yumiko N, Yukari T, Yasuhide T, et al. Differences in behavior among the chlorides of seven rare earth elements administered intravenously to rats. Fundam Appl Toxicol 1997; 37(2): 106-116.

45. Yuen CK and Ip WY. Theoretical risk assessment of magnesium alloys as degradable biomedical implants. Acta Biomater 2010; 6(5): 1808-1812.

46. Drynda A, Deinet N, Braun N, et al. Rare earth metals used in biodegradable magnesium-based stents do not interfere with proliferation of smooth muscle cells but do induce the upregulation of inflammatory genes. J Biomed Mater Res A 2009; 91(2): 360-369.

47. Feyerabend F, Fischer J, Holtz J, et al. Evaluation of short-term effects of rare earth and other elements used in magnesium alloys on primary cells and cell lines. Acta Biomater 2010; 6(5): 1834-1842.

48. Waizy H, Diekmann J, Weizbauer A, et al. In vivo study of a biodegradable orthopedic screw (MgYREZr-alloy) in a rabbit model for up to 12 months. J Biomater Appl. Epub ahead of print 2013. DOI: 10.1177/ 0885328212472215.

49. Song GL and Atrens A. Corrosion mechanisms of magnesium alloys. Adv Eng Mater 1999; 1(1): 11-33.

50. Gu XN, Li N, Zhou WR, et al. Corrosion resistance and surface biocompatibility of microarc oxidation coating on a Mg-Ca alloy. Acta Biomater 2011; 7(4): 1880-1889.

51. Gu XN, Li N, Zheng YF, et al. In vitro degradation performance and biological response of a $\mathrm{Mg}-\mathrm{Zn}-\mathrm{Zr}$ alloy. Mater Sci Eng B 2011; 176(20): 1778-1784.

52. Huan ZG, Leeflang MA, Zhou J, et al. In vitro degradation behavior and cytocompatibility of $\mathrm{Mg}-\mathrm{Zn}-\mathrm{Zr}$ alloys. J Mater Sci Mater Med 2010; 21(9): 2623-2635.

53. Yang L and Zhang E. Biocorrosion behavior of magnesium alloy in different simulated fluids for biomedical application. Mater Sci Eng C 2009; 29(5): 1691-1696.

54. Zhu Y, Wu G, Zhang Y-H, et al. Growth and characterization of $\mathrm{Mg}(\mathrm{OH})_{2}$ film on magnesium alloy AZ31. Appl Surf Sci 2011; 257(14): 6129-6137.

55. Bobe K, Willbold E, Morgenthal I, et al. In vitro and in vivo evaluation of biodegradable, open-porous scaffolds made of sintered magnesium W4 short fibres. Acta Biomater. Epub ahead of print 2013. DOI: 10.1016/j.actbio.2013.03.035.

56. Willumeit R, Feyerabend F and Huber N. Magnesium degradation as determined by artificial neural networks. Acta Biomater. Epub ahead of print 2013. DOI: 10.1016/ j.actbio.2013.02.042.

57. Xin $\mathrm{Y}, \mathrm{Hu} \mathrm{T}$ and $\mathrm{Chu} \mathrm{PK}$. In vitro studies of biomedical magnesium alloys in a simulated physiological environment: A review. Acta Biomater 2011; 7(4): 1452-1459.

58. Harandi SE, Idris $\mathrm{MH}$ and Jafari $\mathrm{H}$. Effect of forging process on microstructure, mechanical and corrosion properties of biodegradable $\mathrm{Mg}-1 \mathrm{Ca}$ alloy. Mater Design 2011; 32(5): 2596-2603.

59. Hort N, Huang Y, Fechner D, et al. Magnesium alloys as implant materials - principles of property design for $\mathrm{Mg}$ RE alloys. Acta Biomater 2010; 6(5): 1714-1725.

60. Atrens A, Liu M and Zainal Abidin NI. Corrosion mechanism applicable to biodegradable magnesium implants. Mater Sci Eng B 2011; 176(20): 1609-1636.

61. Zhang S, Zhang X, Zhao C, et al. Research on an Mg-Zn alloy as a degradable biomaterial. Acta Biomater 2010; 6(2): 626-640. 